\title{
Unraveling the Role of Melatonin/Quercetin in Attenuating the Metabolic and Bone Turnover Alternations in Iron Treated-Ovariectomized Female Rats
}

\author{
RAMEZ A. BARHOMA, M.D.*; ISLAM I. HEGAB, M.D.*; MARWA M. ATEF, M.D.** and \\ AMIRA M. EL-SHAMY, M.D.**
}

The Departments of Physiology* and Biochemistry**, Faculty of Medicine, Tanta University, Egypt

\begin{abstract}
Background: Iron accumulation is involved in many of postmenopausal associated disorders, like osteoporosis.

Aim of Study: This study was designed to evaluate the possible role of iron accumulation in deteriorating the ovariectomy-induced metabolic and bone remodeling alterations with the possible protective effect of melatonin and quercetin in this respect.

Material and Methods: 40 female albino rats were divided into 5 equal groups, 8 rats each; Group 1: Control sham operated group, received intraperitoneal injections of normal saline, 3 times/week after sham operations, Group 2: Ovariectomized (OVX) group, received the same saline treatments after bilateral ovariectomy, Group 3: Iron treated-OVX group (F-OVX), received intraperitoneal injections of $0.04 \mathrm{~g} / \mathrm{kg}$ ferric ammonium citrate 3 times a week after bilateral ovariectomy, Group 4: Melatonin + iron treated-OVX group (MF-OVX), received subcutaneous melatonin injections $(10 \mathrm{mg} / \mathrm{kg})$ daily after bilateral ovariectomy, Group 5: Quercetin + iron treatedOVX group (QF-OVX), received intraperitoneal quercetin injection of $10 \mathrm{mg} / \mathrm{kg} /$ day after bilateral ovariectomy.
\end{abstract}

At the end of the experimental regimen (4 weeks), blood samples were collected and centrifuged, the obtaining serum was used for determination of iron, ferritin, Malondialdehyde (MDA), Total Antioxidant Capacity (TAC) glucose, insulin and insulin resistance (using HOMA-IR equation). Moreover, the serum Total Cholesterol (TC), High Density LipoproteinCholesterol (HDL-C), Low Density Lipoprotein-Cholesterol (LDL-C) and Triglycerides (TG) were assayed along with bone turnover markers including; serum Osteocalcin (OC), Bone Specific Alkaline Phosphatase (BALP) Cross-linked Carboxy-terminal telopeptide of type I collagen (CTX-I) and tartrate-resistant acid phosphatase $5 \mathrm{~b}$ (TRACP5b). Furthermore, livers were removed for determination of liver iron, MDA and TAC levels.

Results: Iron treatment in OVX rats further exacerbated the ovariectomy induced alterations in oxidative status, indicated by increased MDA and decreased TAC in both serum and liver tissue, metabolic status, indicated by significantly

Correspondence to: Dr. Ramez A. Barhoma, E-Mail: ramez.barhoma@Gmail.com elevated serum TC, LDL-C, TG, glucose and HOMA-IR levels, and bone turnover status, indicated by significant decrease in serum markers of bone formation (OC, BALP) and increase in those of bone resorption (CTX-I, TRACP5b), in F-OVX group compared to OVX group. On the other hand, treatment of F-OVX rats with either melatonin or quercetin significantly mitigated all these alterations, which was in concomitance with improvement of the iron status indicated by significant decrease in serum and liver iron along with serum ferritin levels, in MF-OVX and QF-OVX groups compared to F-OVX group.

Conclusion: Melatonin and quercetin improved the metabolic and bone turnover alternations, induced by iron accumulation in treated F-OVX rats, possibly via their iron chelating, antioxidant, insulin sensitizing, hypolipidemic and antiosteoporotic effects, as recorded in this rat model.

Key Words: Iron accumulation - Ovariectomy - Melatonin - Quercetin-Lipid profile - Bone turnover markers.

\section{Introduction}

IRON is one of the most abundant transition metals in the human body, and serves a key function in numerous biological processes, including oxygen transport, DNA synthesis and energy production [1]. Nevertheless, it is a double-edged sword; excess iron is toxic, causing cellular dysfunction, being a powerful catalyst for the generation of highly toxic free radicals that can damage all molecular classes found in vivo [2]. Most importantly, iron accumulation, a recently observed clinical phenomenon in postmenopausal women, was shown to be involved in the pathogenesis of many postmenopausal related disorders $[3,4]$. Clear$1 y$, there is a direct relationship between estrogen and systemic iron metabolism, although the molecular mechanism is still unclear [5]. Whereas estrogen decreases because of the stoppage of ovarian functions, stored body iron, as reflected 
by serum ferritin concentrations, increases rapidly after menopause to reach about more than twice that observed in premenopausal women [6-8]

Although the increased iron stores after menopause is considered to be moderate, compared to the pathological forms of primary and secondary iron overload [9], potential health problems were linked to this increase [10], and could be a risk factor for several chronic diseases such as atherosclerosis, diabetes and metabolic disorders associated with the insulin resistance syndrome [11] Moreover, iron accumulation had been reported as a secondary causative factor in postmenopausal osteoporosis [11-17], and postmenopausal women with abnormally elevated iron are more susceptible to osteoporosis, which could be, partially in part, due to ROS generation [4,17]. Moreover, many studies recorded the deteriorating effect of estrogen deficiency and iron accumulation on glucose and lipid homeostasis in different experimental models [18-22]. Based on these observations, it could be speculated that the postmenopausal accumulation of iron may have a role in exacerbating many of postmenopausal associated pathology with the possible modulating role of substances that have iron chelating and free radicals scavenging capabilities [3,8].

Melatonin is a tryptophan derived hormone secreted from the pineal gland during the dark phase of the daily light/dark cycle [23]. It plays an important role in regulation of many physiological events through its antioxidant and free radical scavenging effects [24-26]. Melatonin is an efficient protector of proteins and lipids in cellular membranes as well as antagonists of many endogenous and exogenous free radicals [27]. A wide range of actions of this hormone make it possible to be used in cancer therapy, Parkinson's disease, Alzheimer's disease, and diabetes [28]. Furthermore, many authors suggested the prophylactic effect of melatonin against iron-induced toxicity [29], and its positive impact in mitigating the metabolic disturbances associated with menopause [20]

Quercetin is a natural dietary flavonoid, present in foods such as fruit, vegetables, and tea. It is well documented for its anti-diabetic [30,31], and antidepressant properties [32,33], and its beneficial effects against disorders of lipid metabolism [34] It also protects against various diseases as pulmonary and cardiovascular diseases, osteoporosis, and aging [35]. It can prevent cell death by scavenging free radicals, protecting against lipid peroxidation [36], and its chelation to metals [37]
Absence of the appropriate rodent animal models that mimic postmenopausal conditions of estrogen and iron levels [3], directed us to establish an ovariectomized, iron-treated female rat model to replicate the characteristics of postmenopausal females [38], so as to study the possible role of iron accumulation in deteriorating the OVX-induced metabolic and bone remodeling alterations with the possible ameliorating effect of melatonin and quercetin treatment in this respect.

\section{Material and Methods}

\section{Chemicals:}

Melatonin, quercetin and elemental iron, in the form of ferric ammonium citrate, were purchased from Sigma Chemical Co. (St. Louis, USA). All drugs were of high analytical grade and freshly prepared.

\section{Animals and study design:}

This current work was performed at Tanta Faculty of Medicine, from November 2018 to February 2019 , and all experiments were conducted according to guidelines of the Ethical Committee of Medical Research, of Tanta Faculty of Medicine, Egypt.

Forty female albino rats, 3 months old (weighing 200-220g), were purchased from the Experimental Animal House of Faculty of Science, Tanta University. The rats were kept in plastic cages (4 rats per cage) at room temperature $\left(23 \pm 2^{\circ} \mathrm{C}\right)$, under controlled environmental conditions, 12/12h light/ dark cycle, with free access to water and food.

The rats were randomly categorized into 5 equal groups, 8 rats each.

Group 1: Control sham operated group, received intraperitoneal injections of normal saline, 3 times a week for 4 weeks after sham operations.

Group 2: Ovariectomized (OVX) group, received the same saline treatments after bilateral ovariectomy.

Group 3: Iron treated-OVX group (F-OVX), received intraperitoneal injections of $0.04 \mathrm{~g} / \mathrm{kg}$ ferric ammonium citrate (dissolved in normal saline), 3 times a week for 4 weeks [14], after bilateral ovariectomy. This dose was chosen so as to induce an increased serum ferritin level to about 2-3 fold [14], which resemble the level present in postmenopausal women [39]

Group 4: Melatonin + iron treated-OVX group (MF-OVX), after bilateral ovariectomy, they re- 
ceived subcutaneous melatonin injections (10 $\mathrm{mg} / \mathrm{kg}$ ) daily for 4 weeks at $4 \mathrm{p} . \mathrm{m}$. (30min before iron administration and $2 \mathrm{~h}$ before light off) $[29,40,41]$

Group 5: Quercetin + iron treated-OVX group (QF-OVX), after bilateral ovariectomy, they received intraperitoneal quercetin injection of 10 $\mathrm{mg} / \mathrm{kg} / \mathrm{day}$, for 4 weeks (30min after iron administration) [42]

\section{Ovariectomy and sham operation:}

Bilateral OVX and sham operations were performed using a dorsal approach through two dorsolateral incisions, approximately $1 \mathrm{~cm}$ long above the ovaries, under intraperitoneal sodium pentobarbital (40mg/kg body weight) anesthesia [43], according to the technique described by Abdel-Sater and Mansour [44]. The ovaries of the OVX group were bilaterally removed while; that of the Shamoperated rats were exteriorized but not removed. After surgery, all the animals were cared with antibiotics and analgesia.

\section{Blood and tissue sampling:}

At the end of the experiment (24 hours after the last medication), all rats had been fasted for 16-18 hours then midline laparotomy was done under anaesthesia, blood samples were collected, centrifuged at $3000 \mathrm{rpm}$ for $15 \mathrm{~min}$. for obtaining serum to be used in biochemical analysis. Then livers of each rat were removed and pieces of them were washed, dried, weighted, then adequate buffer was added $(0.01 \mathrm{M}$ phosphate buffer saline $(\mathrm{pH}$ 7.4) for total iron and MDA, or normal saline for TAC), to prepare $10 \%$ homogenate that was centrifuged at $10000 \mathrm{rpm}$ for $10 \mathrm{~min}$, then the supernatant was removed and used for different assays. Furthermore, total protein contents were determined according to the Biuret method [45]. The liver iron content was assayed herein, to confirm iron accumulation in tissues, considering that the liver is the dominant iron storage site and liver iron concentration predicts the total iron store in the body [46].

\section{1- Determination of serum and liver biochemical markers:}

- Determination of iron in serum and liver homogenates and serum ferritin: Total iron level in serum and liver homogenates were determined using colorimetric iron assay kits (MyBioSource, Inc., USA). Furthermore, serum ferritin, which is the most widely used index for clinically evaluating iron storage [38], was assayed using MyBioSource ELISA Kits following the manufacturers' instructions.
- Determination of serum and liver oxidative stress markers: Malondialdehyde and Total Antioxidant Capacity (TAC) levels were determined in serum and liver homogenates using colorimetric assay kits (MyBioSource, Inc., USA), according to the manufacturers' instructions.

\section{2- Determination of metabolic parameters:}

- Serum glucose, insulin and insulin resistance: Serum glucose level was measured using colorimetric assay kits (Biodiagnostic Chemical Company, Giza, Egypt), and serum insulin was measured by Rat Insulin ELISA kit (MyBioSource, Inc., USA) according to the manufacturers' instructions. Insulin Resistance (IR) was calculated using the Homeostasis Model Assessment of IR (HOMAIR) equation described by Matthews et al., [47] as follows:

$$
\text { HOMA = IR }=\frac{\text { Glucose (mg/dl) X Insulin ( IUml) }}{405}
$$

- Serum lipid profile: Serum Triglycerides (TG), Total Cholesterol (TC), High Density Lipoprotein (HDL-C) and were determined using Biodiagnostic kits (Giza, Egypt) following the manufacturers' instructions. While, LDL-C concentration was calculated using Friedewald equation [48] as follow:

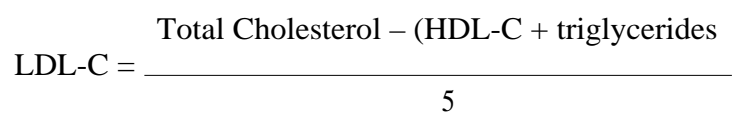

\section{3- Determination of serum bone turnover biomar- kers [49]:}

-Markers of bone formation: Serum Osteocalcin (OC) and Bone Specific Alkaline Phosphatase (BALP) were measured using the rat osteocalcin and rat bone alkaline phosphatase ELISA kits (MyBioSource, Inc., USA) respectively, according to the manufacturers' instructions.

- Markers of bone resorption: Serum Crosslinked Carboxy-terminal telopeptide of type I collagen (CTX-I) and tartrate-resistant acid phosphatase 5b (TRACP5b) were determined using the corresponding rat ELISA kits (MyBioSource, Inc., USA), according to the manufacturers' instructions.

\section{Statistical analysis:}

The statistical analysis was carried out using the SPSS software. The collected data were subjected to one-way ANOVA followed by Tukey's test that used to determine the significance between more than two groups. Data are expressed as the mean \pm SD. $p$-value $<0.05$ was considered significant. 


\section{Results}

Serum and liver iron and serum ferritin levels:

The serum and liver iron concentrations as well as serum ferritin were significantly increased in F-OVX rats compared to OVX rats (Table 1). Treatment with melatonin or quercetin significantly decreased serum and liver iron as well as serum ferritin levels in MF-OVX and QF-OVX compared to F-OVX group (Table 1).

Serum and liver oxidative stress markers:

Table (2) showed that the levels of MDA in serum and liver tissues underwent a significant increase along with a significant decrease in TAC in OVX versus sham operated group as well as in F-OVX versus OVX group. After melatonin or quercetin administration a significant decrease in MDA and increase in TAC were recorded in MFOVX and QF-OVX versus F-OVX group.

\section{Serum glucose, insulin, HOMA-IR and lipid profile:}

The serum levels of insulin and glucose were significantly increased accompanied with significant increase in HOMA-IR in OVX compared to sham operated rats. Further elevation in serum glucose and HOMA-IR was detected in F-OVX group compared to OVX group. Treatment with melatonin or quercetin significantly decreased glucose, insulin and HOMA-IR in MF-OVX and QF-OVX versus F-OVX group, as shown in (Table $3)$.

Simultaneously, serum levels of TG, TC, and LDL-C were significantly increased, whereas HDL-
C was significantly decreased in OVX versus sham operated rats. Following iron treatment, the TG, $\mathrm{TC}$, and LDL-C levels were significantly enhanced in F-OVX versus OVX group. Administration of melatonin or quercetin to the iron treatedovariectomized rats significantly lowered the serum levels of TG, TC, LDL-C, and elevated HDL-C in MF-OVX and QF-OVX compared to F-OVX group, however, melatonin effects were significant in relation to quercetin effects, as presented in (Table 3).

\section{Serum bone turnover biomarkers:}

Results of (Table 4) showed that there was a significant elevation in the sensitive biochemical markers of bone formation, where serum osteocalcin and bone ALP levels were increased by 1.32 and 1.2 folds, respectively, in OVX versus sham operated rats. Moreover, the bone resorping parameters, CTX-I and TRACP5b were also increased by 3.90 and 2.58 , respectively in OVX versus sham operated rats. It is obvious from our results that ovariectomy was associated with a high bone turnover state with bone resorption exceeding bone formation.

Following iron treatment, osteocalcin, and bone ALP were significantly decreased, while CTX-I, and TRACP5b were significantly enhanced in FOVX versus OVX group. Administration of melatonin or quercetin to the iron treated-ovariectomized rats, significantly elevated the serum levels of osteocalcin, and bone ALP, and lowered CTX-I, and TRACP5b in MF-OVX and QF-OVX compared to F-OVX group, as shown in (Table 4).

Table (1): Serum and liver iron and serum ferritin levels for all groups.

\begin{tabular}{llllll}
\hline Parameters & Sham operated & \multicolumn{1}{c}{ OVX } & \multicolumn{1}{c}{ F-OVX } & \multicolumn{1}{c}{ MF-OVX } & QF-OVX \\
\hline Serum iron ( $/ \mathbf{d})$ & $141.85 \pm 17.58$ & $149.39 \pm 19.41$ & $288.22 \pm 29.89 \mathbf{a , b}$ & $151.57 \pm 19.46^{\mathbf{c}}$ & $156.77 \pm 19.70^{\mathbf{a}, \mathbf{c}}$ \\
Iron in liver ( $/$ tissue) & $201.13 \pm 25.93$ & $213.12 \pm 27.15$ & $320.69 \pm 26.70^{\mathbf{a}, \mathbf{b}}$ & $235.75 \pm 31.09^{\mathbf{a}, \mathbf{b}, \mathbf{c}}$ & $239.23 \pm 26.53 \mathbf{a , b}, \mathbf{c}$ \\
Serum ferritin ( $/ \mathbf{g}$ & $39.97 \pm 5.40$ & $39.43 \pm 4.85$ & $116.83 \pm 18.22^{\mathbf{a}, \mathbf{b}}$ & $46.67 \pm 5.36^{\mathbf{c}}$ & $47.59 \pm 6.10^{\mathbf{c}}$ \\
\hline
\end{tabular}

Values are expressed as mean $\pm \mathrm{SD}(\mathrm{n}=8)$

Significance of differences $(p<0.05)$ is illustrated as a versus sham operated group; $\mathbf{b}_{\text {versus OVX; }} \mathbf{c}$ versus F-OVX.

Table (2): Serum and liver oxidative stress markers for all groups.

\begin{tabular}{llllll}
\hline Parameters & Sham operated & \multicolumn{1}{c}{ OVX } & F-OVX & MF-OVX & QF-OVX \\
\hline Serum TAC (mmol/L) & $3.95 \pm 1.05$ & $2.23 \pm 0.45^{\mathbf{a}}$ & $1.27 \pm 0.31^{\mathbf{a}, \mathbf{b}}$ & $2.91 \pm 0.57^{\mathbf{a}, \mathbf{c}}$ & $3.02 \pm 0.41^{\mathbf{a}, \mathbf{c}}$ \\
Serum MDA (nmol/L) & $2.39 \pm 0.54$ & $4.79 \pm 0.84^{\mathbf{a}}$ & $11.56 \pm 1.19^{\mathbf{a}, \mathbf{b}}$ & $2.80 \pm 0.85^{\mathbf{c}}$ & $2.93 \pm 0.78^{\mathbf{c}}$ \\
Liver TAC (nmol/mg ptn) & $37.58 \pm 4.19$ & $31.48 \pm 3.79^{\mathbf{a}}$ & $22.13 \pm 2.98^{\mathbf{a}, \mathbf{b}}$ & $36.23 \pm 4.27^{\mathbf{b}, \mathbf{c}}$ & $36.66 \pm 3.60^{\mathbf{b}, \mathbf{c}}$ \\
Liver MDA (nmol/g ptn) & $315.13 \pm 29.57$ & $386.00 \pm 33.62^{\mathbf{a}}$ & $427.50 \pm 36.38^{\mathbf{a}, \mathbf{b}}$ & $340.75 \pm 27.71^{\mathbf{b}, \mathbf{c}}$ & $345.63 \pm 31.52 \mathbf{a , b , c}$ \\
\hline
\end{tabular}

Values are expressed as mean \pm SD $(n=8)$.

Significance of differences $(p<0.05)$ is illustrated as a versus sham operated group; b versus OVX; c versus F-OVX.

TAC : Total Antioxidant Capacity.

MDA: Malondialdehyde. 
Table (3): Serum lipid profile, glucose, insulin, and HOMA-IR for all groups.

\begin{tabular}{|c|c|c|c|c|c|}
\hline Parameters & Sham operated & OVX & F-OVX & MF-OVX & QF-OVX \\
\hline TG (mg/dl) & $88.50 \pm 10.19$ & $116.63 \pm 22.50^{\mathrm{a}}$ & $132.50 \pm 16.89^{\mathbf{a}^{\prime} \mathbf{b}}$ & $93.00 \pm 12.50^{\mathbf{b}} \mathbf{c}$ & $109.38 \pm 13.34^{\mathbf{a}^{\prime} \mathbf{b}^{\prime} \mathbf{c} \mathbf{c}^{\prime} \mathbf{d}}$ \\
\hline Total cholesterol (mg/dl) & $138.25 \pm 16.82$ & $160.75 \pm 25.73^{\mathrm{a}}$ & $203.00 \pm 24.21$ a,b & $138.00 \pm 19.34 \mathbf{b}^{\mathbf{b}} \mathbf{c}$ & $158.38 \pm 23.70^{\mathbf{a}^{\prime} \mathbf{c}^{\prime} \mathbf{d}}$ \\
\hline HDL-C (mg/dl) & $49.25 \pm 4.23$ & $44.75 \pm 5.28 \mathbf{a}$ & $43.38 \pm 5.19^{a}$ & $64.38 \pm 7.41$ a,b,c & $59.13 \pm 6.72^{\mathbf{a}^{\prime} \mathbf{b}^{\prime} \mathbf{c}^{\prime} \mathbf{d}}$ \\
\hline LDL-C (mg/dl) & $73.00 \pm 8.27$ & $96.13 \pm 10.39^{a}$ & 129. $10 \pm 14.29^{\mathbf{a}^{\prime} \mathbf{b}}$ & $76.38 \pm 9.26^{\mathbf{b}} \mathbf{c}$ & $88.00 \pm 9.55^{\mathbf{a}^{\prime} \mathbf{c}^{\prime} \mathbf{d}}$ \\
\hline Glucose (mg/dl) & $87.75 \pm 10.50$ & $103.88 \pm 15.49^{\mathrm{a}}$ & $114.75 \pm 15.61 \mathbf{a , b}$ & $90.00 \pm 11.84^{\mathbf{b}} \mathbf{c}$ & $91.63 \pm 10.19^{\mathbf{b}} \mathbf{c}$ \\
\hline Insulin ( IUml) & $4.73 \pm 0.96$ & $13.33 \pm 1.83 \mathbf{a}$ & $12.78 \pm 1.95 \mathrm{a}$ & $5.94 \pm 1.51 \mathbf{b}, \mathbf{c}$ & $5.86 \pm 1.41$ b'c \\
\hline HOMA-IR & $0.98 \pm 0.22$ & $3.04 \pm 0.56^{\mathbf{a}}$ & $3.46 \pm 0.93^{\mathbf{a}, \mathbf{b}}$ & $1.32 \pm 0.15 \mathbf{a}, \mathbf{b}, \mathbf{c}$ & $1.35 \pm 0.15^{\mathbf{a}^{\prime} \mathbf{b}} \mathbf{c}$ \\
\hline
\end{tabular}

Values are expressed as mean $\pm \mathrm{SD}(\mathrm{n}=8)$.

Significance of differences $(p<0.05)$ is illustrated as ${ }^{\mathbf{a}}$ versus sham operated group; b versus OVX; c versus F-OVX; d versus MF-OVX. TG : Triglycerides.

HDL-C: High Density Lipoprotein-Cholesterol.

LDL-C: Low Density Lipoprotein-Cholesterol.

Table (4): Serum bone turnover markers for all groups.

\begin{tabular}{llllll}
\hline Parameters & Sham operated & \multicolumn{1}{c}{ OVX } & F-OVX & MF-OVX & QF-OVX \\
\hline Serum osteocalcin (ng/ml) & $74.00 \pm 9.93$ & $98.07 \pm 8.27^{\mathbf{a}}$ & $71.37 \pm 6.93^{\mathbf{b}}$ & $83.79 \pm 3.17^{\mathbf{a}^{\prime} \mathbf{b}^{\prime} \mathbf{c}}$ & $85.44 \pm 2.77^{\mathbf{a}^{\prime} \mathbf{b} \mathbf{b}^{\prime} \mathbf{c}}$ \\
Bone ALP (U/dl) & $14.25 \pm 2.39$ & $17.13 \pm 2.64^{\mathbf{a}}$ & $11.09 \pm 1.60^{\mathbf{a} \mathbf{b}}$ & $13.78 \pm 1.50^{\mathbf{b}^{\prime} \mathbf{c}}$ & $13.41 \pm 2.17^{\mathbf{b}^{\prime} \mathbf{c}}$ \\
CTX-I (Pmol/l) & $2499.8 \pm 530.14$ & $9745.8 \pm 758.99 \mathbf{a}$ & $13239 \pm 914.39^{\mathbf{a} \mathbf{b}}$ & $5270 \pm 644.70^{\mathbf{a} \mathbf{\prime}^{\prime} \mathbf{c} \mathbf{c}}$ & $6312.9 \pm 590.93^{\mathbf{a}, \mathbf{b}, \mathbf{c}, \mathbf{d}}$ \\
TRACP5b (U/l) & $23.44 \pm 4.12$ & $60.44 \pm 7.35^{\mathbf{a}}$ & $80.31 \pm 9.1 \mathbf{a}^{\mathbf{a}, \mathbf{b}}$ & $28.22 \pm 3.88^{\mathbf{b}^{\prime} \mathbf{c}}$ & $26.92 \pm 3.92^{\mathbf{b} \mathbf{b}^{\prime} \mathbf{c}}$ \\
\hline
\end{tabular}

Values are expressed as mean $\pm \mathrm{SD}(\mathrm{n}=8)$.

Significance of differences $(p<0.05)$ is illustrated as ${ }^{\mathbf{a}}$ versus sham operated group; b versus OVX; $\mathbf{c}$ versus F-OVX; $\mathbf{d}$ versus MF-OVX. Bone ALP: Bone specific alkaline phosphatase.

CTX-I : Cross-linked Carboxy-terminal telopeptide of type I collagen.

TRACP5b: Tartrate-resistant acid phosphatase $5 \mathrm{~b}$.

\section{Discussion}

Studies showed that concurrent but inverse changes in iron and estrogen levels occurs during the menopausal transition with a sequel of increased iron accumulation after menopause that was linked to many disorders associated with menopause [3] Thereby, in this current study, we generated an OVX rat model with an elevated iron to replicate the characteristic of postmenopausal females [38]; so as to evaluate the possible modulating effect of melatonin or quercetin treatment on the associated metabolic and bone turnover alternations in this rat model.

Our results showed that treatment with iron for 4 weeks, significantly increased the serum iron and ferritin levels along with liver iron content in F-OVX group versus OVX group, confirming iron accumulation in sera and tissue of this rat model, as shown previously $[\mathbf{1 4 , 3 8}]$. Moreover, we observed that this excess iron accumulation was in concomitance with exacerbation of the ovariectomyinduced metabolic and bone turnover alternations, referring to the involvement of excess iron accumulation in aggravating the ovariectomy associated pathology with possible ameliorating role of iron chelating agents in this aspect.
Noteworthy, administration of either melatonin or quercetin significantly decreased iron in sera and liver of MF-OVX and QF-OVX groups versus F-OVX group, denoting their iron chelating effects, which was in accord with previous studies $[29,42,50]$

The mechanisms underlying the iron chelating effect of melatonin could be attributed to its ability to form complexes with iron removing it and preventing its reduction and subsequent generation of free radicals [51]. Small size of melatonin was suggested to allow its direct access to the iron core of ferritin, inhibiting redox cycling and generation of toxic Reactive Oxygen Species (ROS) [52] Additionally, the high lipophilicity of melatonin allows its movement across cell barriers and removal of toxic metals $[\mathbf{5 3 , 5 4}]$. On the other side, quercetin was shown to facilitate iron movement between intracellular and extracellular compartments; reducing the iron overload [55]. Furthermore, it could increase iron excretion [56]; via formation of quercetin-iron (II) complex that can pass through glucose transporter 1, thus decreasing the intracellular iron and its related radical production [57-59] Quercetin could also reduce serum iron [60], through chelating iron within the intestinal lumen, via its 3-hydroxyl group, and regulating ferroportin trans- 
porter expression, in acute and chronic iron overload conditions [60]

It is well documented that oxidative status depends on the balance between oxidants and antioxidants, with the TAC concentration being an overall indicator of oxidative status [61]. Accordingly, our findings revealed a significantly increased MDA level associated with a significantly decreased TAC in the sera and livers of OVX group compared to the sham group, and of F-OVX group compared to OVX group; revealed an ovariectomy-induced oxidative stress, further exaggerated by excess iron accumulation. In harmony, enhancement of oxidative stress response in ovariectomized $[6 \mathbf{6 2 , 6 3}]$, and iron overloaded conditions [29,64] were previously recorded, which could be a key process involved in mediating the pathology induced by ovariectomy and/or excess iron accumulation.

In line with this proposal, the lack of protective antioxidant action of estrogen after ovariectomy may perturb the balance between oxidants and antioxidants status which could be linked to many of ovariectomy-related pathogeneses including; IR [22], non-alcoholic steatohepatitis $[\mathbf{6 5 , 6 6}]$ and osteoporosis $[67,68]$. In addition, Iron is a well-known inducer of ROS, accelerating the lipid peroxidation with marked loss of total antioxidant capacity level $[\mathbf{2 9 , 6 9 , 7 0 ]}$. Iron could catalyze the conversion of hydrogen peroxide to free radical ions via the fenton reaction with a sequel of damaging the biomolecules, including lipids, proteins and DNA [71], which could be the main pathogenic mechanism mediating the toxic effects of iron [42]. Thereby, we may hypothesize that both excess iron and ovariectomy might result in compounded levels of ROS production in F-OVX rats, which could further, promote the ovariectomy induced pathology; as regarding the metabolic derangement and bone turnover alterations, as represented later in this current study.

On the other hand, administration of either melatonin or quercetin herein significantly improved the redox status; which could play a role in mitigating the underlying pathology. This could be mediated via either; their direct antioxidant effects or; indirectly through chelating iron with its mediated free radicals' generation.

In line with this proposal, melatonin was shown to counteract oxidative stress induced by ovariectomy [72] and iron overload [29]. Melatonin was considered as one of the most potent antioxidants, possibly by its free radical scavenging properties and/or by inhibiting their generation, stimulating antioxidant enzymes and inhibiting the activity of pro-oxidative enzymes $[\mathbf{2 4 , 7 3 , 7 4 ]}$. Moreover, melatonin was shown to protect the liver via attenuating the lipid peroxidation and improving the liver antioxidant defenses [29,72]. Meanwhile, the antioxidant effect of quercetin [42,75] could be attributed to its direct free radicals scavenging capacity [76] beside its ability to facilitate electron export, functioning as an electron donor, thus reducing accumulation of intracellular ROS [77]. Moreover, Li et al., [78] demonstrated that, quercetin inhibited abnormal intercellular labile iron pool and its associated oxidative damage.

It is well known that ovariectomy produces general changes in the metabolism [79]. Consistently, the present study presented an ovariectomyinduced disturbance in glucose homeostasis with IR, indicated by significantly elevated levels of fasting blood glucose, insulin levels and HOMAIR in OVX rats versus sham control ones, which was supported previously $[\mathbf{2 0 , 8 0 ]}$. This could be explained by that deficiency of female sex hormones results in declined insulin-stimulated glucose disposal [81], which could be attributed to ovariectomy-induced increment of visceral fat, dyslipidemia, and impaired glucose tolerance with defective insulin-mediated glucose clearance [19]

Following iron administration herein, further elevation in serum glucose and HOMA-IR was detected in F-OVX group compared to OVX group, which came in line with earlier studies, clarifying a relationship between excess iron accumulation or high iron intake and IR [82-85]. Consistently, iron overload was correlated with the development of diabetes [21,86]. Moreover, iron-induced oxidative stress has been implicated in aggravating the IR [87]. The altered insulin sensitivity in ironoverloaded animals could be attributed to modifying the transcription and membrane affinity of insulin receptor expression in the liver, and by affecting insulin-dependent gene expression [88]. Furthermore, excess iron was shown to interfere with glucose disposal from liver [89,90]

Interestingly, administration of melatonin or quercetin significantly improved IR parameters in MF-OVX and QF-OVX groups versus untreated F-OVX group, which agree previous studies [20, 91-94]. This could be attributed to their iron chelating effect, where iron depletion was shown to increase the insulin sensitivity [95]; possibly by increasing insulin receptor expression in skeletal muscles [96]. Also, their antioxidant effects observed herein, could have a role; awing to the involvement of oxidative stress in IR pathogenesis [97], with 
ability of antioxidant therapy to improve insulin signaling in vitro [98] and glycemic control in diabetic individuals [99]. Meanwhile, the insulin sensitizing effect of quercetin could be mediated either via; its inhibition to a-glucosidase $[\mathbf{1 0 0 , 1 0 1 ]}$ reducing carbohydrates digestion [102]; or through its activation to hepatic protein kinase $\mathrm{B}$ which consequently increased hepatic glycogen synthesis and reduced blood glucose levels [103].

The results obtained from this current study, also elucidated that, the disruption of glucose homeostasis after ovariectomy was associated with disturbance in lipid profile, as manifested by significantly increased levels of serum total cholesterol, LDL-C, and TG whereas, HDL-C levels were significantly decreased in OVX group versus sham control group. These results are in accordance with previous studies $[\mathbf{1 0 4 , 1 0 5 ]}$. Estrogen has been shown to increase HDL-C and decrease LDL-C levels [106]. Furthermore, the number of LDL liver receptors is reduced during the menopause $[\mathbf{1 0 7 , 1 0 8}]$ This disturbed lipid metabolism may be a cause or a consequence of IR [109].

Additionally, iron administration further deteriorated the lipid profile in F-OVX versus OVX group, referring to the exacerbating role of iron on hyperlipidemia as recorded previously [18]. In consistence, a significant increase in cholesterol and TG were recorded after iron supplementation [110,111]. Excess iron accumulation was shown to interfere with plasma lipid transport, resulting in increased TG and cholesterol levels [111,112]. Moreover, the iron-induced membrane lipid peroxidation was considered as an important factor in altering lipid metabolism [111] ; possibly by its effect on lipogenesis-related genes [113] and key enzymes necessary for cholesterol homeostasis [114]

Intriguingly, administration of either melatonin or quercetin to F-OVX group significantly improved their lipid profile comparable with their non-treated F-OVX counterparts, signifying the hypolipidemic effect of melatonin $[\mathbf{1 1 5 , 1 1 6 ]}$, and quercetin [103,117]. This could be explained by their iron chelating effect where; iron depletion was shown to improve the lipid profile disturbed by high dietary iron [118-120]. Additionally, melatonin supplementation was found to be effective or even better than estrogen replacement therapy in correcting ovariectomy-induced dyslipidemia [20], which could be mediated mostly via; its antioxidative potentials and its suppression to the levels of pro-inflammatory cytokines which consequently prevents LDL oxidation [121,122]. Additionally, the hypocholesterolemic effect of melatonin could be mediated via its augmentation to endogenous cholesterol clearance mechanisms [123], its reduction to the numbers of LDL receptors and its inhibition to cholesterol synthesis [121]. On the other side, the hypolipidemic effect of quercetin could be also attributed to its regulation to sterol regulatory element-binding proteins [124] and LDL receptor protein expression [125]. Kobori et al., [34] demonstrated that quercetin decreased expression of peroxisome proliferator-activated receptor- $\mathrm{a}$ in the liver with subsequent decreased synthesis of TG. It could also reduce de novo fatty acid and TG synthesis and acetyl-CoA carboxylase activity in rat hepatocytes [126]

Our results also revealed that ovariectomy was associated with increased bone turnover markers, of bone resorption; serum CTX and TRACP5b, and bone formation; serum osteocalcin and bone ALP, with bone resorption exceeding formation, reflecting a high bone turnover rate which may be responsible for bone loss, as shown previously $[44,38,127,128]$. These findings supported the fact that bone resorption is accelerated by estrogen deficiency [129], which could be attributed to stimulation of osteoclasts differentiation and proliferation mediated by ovariectomy -induced oxidative stress $[12,130]$, or increase in parathyroid hormone level [131]

Moreover, our investigations showed that iron administration further disrupted the balance between bone formation and bone resorption, where bone resorption was significantly enhanced, whereas bone formation was significantly depressed. Similar results were recorded previously [38], supporting the hypothesis of that the postmenopausal women with abnormally elevated iron are more susceptible to osteoporosis [4,17]. Consistently, a recent study stated that bone mass was minimally affected by an excess of iron in the presence of estrogen. Once the source of estrogen was removed by ovariectomy, iron accumulation significantly decreased bone mass [38]. Moreover, a decline in bone mineral density was shown to be linked to increased serum ferritin concentration and liver iron content in rats [46]

Studies recorded that iron induced bone loss was attributable to the catalyzing effect of iron in the formation of ROS [131], which had been shown to promote the differentiation of osteoclasts and promote the bone resorption [14,133,134] . Moreover, its effect on bone could be mediated via either; increasing inflammatory cytokines [135], which had been implicated in the etiology of bone resorption [136]; or via down-regulating the Runx 2 ex- 
pression and its downstream targets, osteocalcin and ALP in osteoblasts, leading to attenuation of extracellular matrix mineralization in these cells, triggering osteoporosis [137]

Importantly, administration of melatonin or quercetin to the F-OVX rats, significantly depressed bone resorption, as revealed by decreased CTX-1 and TRACP5b, while bone formation was significantly enhanced, as manifested by increased osteocalcin and bone ALP in treated F-OVX rats versus untreated F-OVX ones, denoting their bone sparing effects, which came in line with previous studies [138-140]. This could be mediated, at least in part, via their iron chelating effects, since treatment with iron chelators was shown to mitigate the loss of bone mass and the deterioration of bone microarchitecture in rats $[\mathbf{1 1}, \mathbf{1 4 1}]$. Furthermore, their scavenging antioxidant potentials could have a role $[\mathbf{1 3 8 , 1 4 2}]$, as free radical scavengers could partially prevent the iron overload-induced bone abnormalities, improving osteoporosis [135]. Additionally, both melatonin and quercetin treatment recorded beneficial direct anti-osteoporotic potentials which could contribute to their bone sparing effects in our model [138-140]. The anti-osteoporotic effect of melatonin could be attributed to its ability to accelerate the osteoblastic cells proliferation and to increase the gene expression of bone marker proteins, including sialoprotein, alkaline phosphatase, osteopontin, and osteocalcin [143,144] Melatonin could also promote osteoblast differentiation and matrix mineralization [138], at least in part, via its free radicals scavenging properties [138]. Meanwhile, the bone sparing effect of quercetin could be mediated either; indirectly via its antioxidant and anti-inflammatory capacities [142] or directly; via its effect on cells of bone remodeling [140]. Quercetin could increase the osteogenic activity of osteoblasts [145]. Moreover, it could modulate osteoclastic resorption of osteoclasts in vitro [146]. The anti-resorptive effect of quercetin could be mediated via suppressing both, differentiation and activation of osteoclasts [147], as well as its ability to induce apoptosis of mature osteoclasts [146]. Another indirect explaining mechanism of the bone-restoring activity of quercetin is mediated via its enhancement to calcium absorption from small intestine and improvement of Vitamin D receptor activity that regulates calcium homeostasis at gene level [148]

\section{Conclusion:}

From this study, we concluded that both melatonin and quercetin are effective in controlling the metabolic derangement and bone turnover alternations, induced by iron accumulation in OVX rats, with the former more effective in maintaining the metabolic homeostasis. These effects could be mediated mostly via; their iron chelating effects which was further enhanced by their antioxidant, insulin sensitizing, hypolipidemic and antiosteoporotic potentials, as recorded in this rat model. These findings may provide an adequate support for developing melatonin or quercetin supplementation therapy either alone, or in combination with estradiol as a possible alternative to estrogen replacement therapy in postmenopausal women.

\section{References}

1- MACKENZIE E.L., IWASAKI K. and TSUJI Y.: Intracellular iron transport and storage: From molecular mechanisms to health implications. Antioxid Redox Signal, 10: 997-1030, 2008.

2- WESSLING-RESNICK M.: Excess iron: Considerations related to development and early growth. Am. J. Clin. Nutr., 106 (1): 1600S-1605S, 2017.

3- JIAN J., PELLE E. and HUANG X.: Iron and menopause: Does increased iron affect the health of postmenopausal women? Antioxid Redox Signal, 11 (12): 2939-43, 2009

4- KIM B.J., AHN S.H., BAE S.J., KIM E.H., LEE S.H., KIM H.K., CHOE J.W., KOH J.M. and KIM G.S.: Iron overload accelerates bone loss in healthy postmenopausal women and middle-aged men: A 3-year retrospective longitudinal study. Journal of Bone and Mineral Research, 27: 2279-90, 2012.

5- YANG Q., JIAN J., KATZ S., ABRAMSON S.B. and HUANG X.: 17p-Estradiol inhibits iron hormone hepcidin through an estrogen responsive element half-site. Endocrinology, 153 (7): 3 170-8, 2012.

6- HOWES P.S., ZACHARSKI L.R., SULLIVAN J. and CHOW B.: Role of stored iron in atherosclerosis. J. Vasc. Nurs., 18: 109-14, 2000.

7- ZACHARSKI L.R., ORNSTEIN D.L., WOLOSHIN S and SCHWARTZ L.M. : Association of age, sex, and racewith body iron stores in adults: Analysis of NHANES III data. Am. Heart J., 140: 98-104, 2000.

8- CHEN B., LI G.F., SHEN Y., HUANG X. and XU Y.J. "Reducing iron accumulation: A potential approach for the prevention and treatment of postmenopausal osteoporosis," Experimental and Therapeutic Medicine, 10 (1): 7-11, 2015

9- KATO I. DNISTRIAN AM, SCHWARTZ M, TONIOLO P., KOENIG K., SHORE R., et al.: Risk of iron overload among middle-aged women. Int. J. Vitam. Nutr. Res., 70 $119-25,2000$

10- SULLIVAN J.L. : Is stored iron safe? J. Lab. Clin. Med., 144: 280-4, 2004.

11-LIU G., MEN P., KENNER G.H. and MILLER S.C.: Ageassociated iron accumulation in bone: Implications for postmenopausal osteoporosis and a new target for prevention and treatment by chelation. Biometals, 19 (3): 245 $51,2006$. 
12- ISOMURA H., FUJIE K., SHIBATA K., INOUE N., IIZUKA T., TAKEBE G., TAKAHASHI K., NISHIHIRA J., IZUMI H. and SAKAMOTO W.: Bone metabolism and oxidative stress in postmenopausal rats with iron overload. Toxicology, 197 (2): 93-100, 2004.

13-KATSUMATA S., TSUBOI R., UEHARA M. and SUZUKI K.: Dietary iron deficiency decreases serum osteocalcin concentration and bone mineral density in rats. Biosci. Biotechnol. Biochem., 70: 2547-50, 2006.

14- JIA P., XU Y.J., ZHANG Z.L., LI K., LI B., ZHANG W. and YANG H.: Ferric ion could facilitate osteoclast differentiation and bone resorption through the production of reactive oxygen species. J. Orthop. Res., 30 (11): 1843$52,2012$.

15- LI G.F., PAN Y.Z., SIROIS P., LI K. and XU Y.J.: Iron homeostasis in osteoporosis and its clinical implications. Osteoporosis International, 23: 2403-8, 2012.

16- HE Y.F., MA Y., GAO C., ZHAO G.Y., ZHANG L.L., LI G.F., PAN Y.Z., LI K. and XU Y.J.: Iron overload inhibits osteoblast biological activity through oxidative stress. Biological Trace Element Research, 152: 292-6, 2013.

17- KIM B.J., LEE S.H., KOH J.M. and KIM G.S.: The association between higher serum ferritin level and lower bone mineral density is prominent in women \ 45 years of age (KNHANES 2008-2010). Osteoporosis International, 24: 2627-37, 2013.

18- KIM S.H., YADAV D., KIM S.J., KIM J.R. and CHO K.H.: High Consumption of Iron Exacerbates Hyperlipidemia, Atherosclerosis, and Female Sterility in Zebrafish via Acceleration of Glycation and Degradation of Serum Lipoproteins. Nutrients, 9 (7): 690, 2017.

19- SAENGSIRISUWAN V., PONGSEEDA S., PRASANNARONG M., VICHAIWONG K. and TOSKULKAO C.: Modulation of insulin resistance in ovariectomized rats by endurance exercise training and estrogen replacement. Metab. Clin. Exp., 58: 38-47, 2009.

20- BAXI D., SINGH P.K., VACHHRAJANI K. and RAMACHANDRAN A.V.: Melatonin supplementation therapy as a potent alternative to ERT in ovariectomized rats Climacteric, 15 (4): 382-92, 2012.

21- SMOTRA S. and KUDYAR R.P.: Relationship between serum ferritin and type-2 diabetes mellitus. JK Science, 10 (4): 170-4, 2008.

22- ABBAS A.M. and ELSAMANOUDY A.Z.: Effects of $17(3$-estradiol and antioxidant administration on oxidative stress and insulin resistance in ovariectomized rats. Can. J. Physiol. Pharmacol., 89 (7): 497-504, 2011.

23- REBAI R., BOUDAH A. and DERRI N.: Melatonin and quercetin improve depressive-like behavior and dyslipidemia in streptozotocin-induced diabetes in rats The $\mathbf{J}$. Anim. Plant Sci., 27 (6): 2081-5, 2017.

24- REITER R.J.: Melatonin: Clinical relevance. Best Pract. Res. Clin. Endocrinol. Metab., 17: 273-85, 2003.

25- ZAMINY A., KASHANI I.R., BARBARESTANI M., HEDAYATPOUR A., MAHMOUDI R., VARDASBI S., et al.: Effects of melatonin on the proliferation and differentiation of rat adipose-derived stem cells. Indian J. Plastic Surgery, 41: 8-14, 2008.

26- SHIRAZI A., HADDADI G.H., GHAZI-KHANSARI M., ABOLHASSANI F., MAHDAVI S.R. and ESHRAGHY-
AN M.R.: Evaluation of melatonin for prevention of radiation myelopathy in irradiated cervical spinal cord. Yakhteh, 11: 43-8, 2009.

27- CUZZOCREA S. and REITER R.J.: Pharmacological action of melatonin in shock, inflammation and ischemia/ reperfusion injury. Eur. J. Pharmacol., 426: 1-10, 2001.

28- SRINIVASAN V.: Melatonin oxidative stress and neurodegenerative diseases. Indian J. Exp. Biol., 40: 668-79, 2002 .

29- ABD ELKADER M.A.E. and ALY H.F.: Protective effect of melatonin against iron overload-induced toxicity in rats. Int. J. Pharm. Pharm. Sci., 7 (9): 116-21, 2015.

30- IBARRA J., BLAND M., GONZALEZ M. and GARCIA C.: Quercetin ameliorates hyperglycemia-induced inflammation and apoptosis in the retina and lateral geniculate nucleus in a rat model of type 2 diabetes mellitus (688.8). FASEB J., 28: 688-8, 2014.

31- EID H.M., NACHAR A., THONG F., SWEENEY G. and HADDAD P.S.: The molecular basis of the antidiabetic action of quercetin in cultured skeletal muscle cells and hepatocytes. Pharmacogn. Mag., 11 (41): 74-81, 2015.

32- HOLZMANN I., Da SILVA L.M., Da SILVA J.A.C. STEIMBACH V.M.B. and De SOUZA M.M.: Antidepressant-like effect of quercetin in bulbectomized mice and involvement of the antioxidant defenses, and the glutamatergic and oxidonitrergic pathways. Pharmacol. Biochem. Behav., 136: 55-63, 2015.

33- DEMIR E.A., GERGERLIOGLU H.S. and OZ M.: Antidepressant-like effects of quercetin in diabetic rats are independent of hypothalamic- pituitary-adrenal axis. Acta Neuropsychiatr., 28 (1): 23-30, 2016.

34- KOBORI M., MASUMOTO S., AKIMOTO Y. and OIKE H.: Chronic dietary intake of quercetin alleviates hepatic fat accumulation associated with consumption of a Western-style diet in C57/BL6J mice. Mol. Nutr. Food Res. 55: 530-40, 2011.

35- BOOTS A.W., HAENEN G.R.M.M. and BAST A.: "Health effects of quercetin: from antioxidant to nutraceutical," European Journal of Pharmacology, 585 (2-3): 325-37, 2008.

36- PARK C., SO H., SHIN C., BAEK S., MOON B., SHIN S., et al.: Quercetin protects the hydrogen peroxideinduced apoptosis via inhibition of mitochondrial dysfunction in $\mathrm{H} 9 \mathrm{c} 2$ cardiomyoblast cells. Biochemical Pharmacology, 66 (7): 1287-95, 2003.

37- COSKUN O., KANTER M., ARMUTCU F., CETIN K., KAYBOLMAZ B. and YAZGAN O.: "Protective Effects of Quercetin, A Flavonoid Antioxidant, in Absolute Ethanol-Induced Acut Gastric Ulcer," European Journal of General Medicine, 1 (3): 37-42, 2004.

38- XIAO W., BEIBEI F., GUANGSI S., YU J., WEN Z., XI $H$. and YOUJIA X.: Iron overload increases osteoclastogenesis and aggravates the effects of ovariectomy on bone mass. J. Endocrinol., 226 (3): 121-34, 2015.

39- HUANG X., XU Y. and PARTRIDGE N.C.: Dancing with sex hormones, could iron contribute to 468 the gender difference in osteoporosis? Bone, 55: 458-60, 2013.

40- SHAGIRTHA K., MUTHUMANI M. and MILTON PRABU S.: Melatonin abrogates cadmium induced oxidative stress related neurotoxicity in rats. European Review for 
Medical and Pharmacological Sciences, 15: 1039-50, 2011.

41- WANG T.Y., LI Y., WU X., YANG X.L., WANG Y. and WANG D.: Protective Effects of Melatonin on CCl4induced Acute Liver Damage and Testicular Toxicity in Rats. Indian J. Pharm. Sci., 80 (6): 1100-7, 2018.

42- EL-SHEIKH A.A., AMEEN S.H. and ABD EL-FATAH S.S.: Ameliorating Iron Overload in Intestinal Tissue of Adult Male Rats: Quercetin vs Deferoxamine. Journal of Toxicology, 2018: ID 8023840, 2018.

43- TURKOZAN N., ULUSOY A., BALCIOGLU H., BAL F. and OZEL S.: The effects of ovariectomy and naproxen treatment on the strength of femoral midshaft and molar alveolar region in rats. Int. J. Morphol., 27 (3): 659-66, 2009.

44- ABD EL-SATER K.A. and MANSOUR H.: Bone biomarkers of ovariectomized rats after leptin therapy. Bratisl Lek Listy, 114 (6): 303-7, 2013.

45- REINHOLD J.C.: Estimation of serum total proteins by Biuret method,Standard methods in clinical Chemistry, M. Reiner (ED), Acadamic Press, New York, 1: 88, 1953.

46- CHEN L., ZHU Z., PENG X., WANG Y., WANG Y., CHEN M., et al.: Hepatic magnetic resonance imaging with $\mathrm{T} 2 *$ mapping of ovariectomized rats: Correlation between iron overload and postmenopausal osteoporosis. Eur. Radiol., 24: 1715-24, 2014.

47- MATTHEWS D.R., HOSKER J.P., RUDENSKI A.S., NAYLOR B.A., TREACHER D.F. and TURNER R.C.: Homeostasis model assessment: Insulin resistance and beta-cell function from fasting plasma glucose and insulin concentrations in man. Diabetologia, 28: 412-9, 1985.

48- FRIEDEWALD W.T., LEVY R.I. and FREDRICKSON D.S.: Estimation of the concentration of low-density lipoprotein cholesterol in plasma, without use of the preparative ultracentrifuge. Clin. Chem., 18: 499-502, 1972.

49- WHEATER G., ELSHAHALY M., TUCK S.P. and LAAR V.: The clinical utility of bone marker measurements in osteoporosis. J. Transl. Med., 11: 201, 2013.

50- ZHANG Y., LI H., ZHAO Y. and GAO Z.: Dietary supplementation of baicalin and quercetin attenuates iron overload induced mouse liver injury. Eur. J. Pharmacol., 535 (1-3): 263-9, 2006.

51- LIMSON J., NYOKONG T. and DAYA S.: The interaction of melatonin and its precursors with aluminium, cadmiun, copper, iron, lead and zincan adsorptive voltammetric study. J. Pineal. Res., 1: 15-21, 1998.

52- OTHMAN A.I., EL-MIS SIRY M.A., AMER M.A. and ARAFA M.: Melatonin controls oxidative stress and modulates iron, ferritin, and transferrin levels in adriamycin treated rats. Life Sci., 83: 563-8, 2008.

53- REITER R.J.: Melatonin: Lowering the high price of free radicals. News Physiol. Sci., 15: 246-50, 2000.

54- EL-SOKKARY G.H., ABDEL-RAHMAN G.H. and KAMEL E.S.: Melatonin protects against lead-induced hepatic and renal toxicity in male rats. Toxicology, 213: 25-33, 2005.

55- SHANZER A., LIBMAN J., LYTTON S., GLICKSTEIN $\mathrm{H}$. and CABANTCHIK Z.: Reversed siderophores act as antimalarial agents. Proc. Natl. Acad. Sci. USA, 88: 65859, 1991.

56- CABANTCHIK Z.I., BREUER W., ZANNINELLI G. and CIANCIULLI P.: "LPI-labile plasma iron in iron overload," Best Practice \& Research Clinical Haematology, 18 (2): 277-87, 2005.

57- ERLUND I., FREESE R., MARNIEMI J., HAKALA P. and ALFTHAN G.: Bioavailability of quercetin from berries and the diet. Nutr. Cancer, 54: 13-7, 2006.

58- VLACHODIMITROPOULOU E., SHARP P.A. and NAFTALIN R.J.: Quercetin-iron chelates are transported via glucose transporters. Free Radic. Biol. Med., 50 (8): 93444, 2011.

59- BACCAN M.M., CHIARELLI-NETO O., PEREIRA R.M.S. and ESPOSITO B.P.: "Quercetin as a shuttle for labile iron,” Journal of Inorganic Biochemistry, 107 (1): 34-9, 2012.

60- LESJAK M., HOQUE R., BALESARIA S., SKINNER V., DEBNAM E.S., SRAI S.K.S., et al.: "Quercetin inhibits intestinal iron absorption and ferroportin transporter expression in vivo and in vitro", PLoS ONE, 9 (7): e 102900, 2014.

61- SWAIN J.H., ALEKEL D.L., DENT S.B., PETERSON C.T. and REDDY M.B.: Iron indexes and total antioxidant status in response to soy protein intake in perimenopausal women. Am. J. Clin. Nutr., 76: 165-71, 2002.

62- RODRIGUES M.F., STOTZER U.S., DOMINGOS M.M., DEMINICE R., SHIGUEMOTO G.E., TOMAZ L.M., et al.: Effects of ovariectomy and resistance training on oxidative stress markers in the rat liver. Clinics (Sao Paulo), 68 (9): 1247-54, 2013.

63- MUTHUSAMI S., RAMACHANDRAN I., MUTHUSAMY B., VASUDEVAN G., PRABHU V., SUBRAMANIAM V., et al.: Ovariectomy induces oxidative stress and impairs bone antioxidant system in adult rats. Clin. Chim. Acta., 360: 81-6, 2005.

64- ABD EL-BAKY A., ABDULLAH A. and ABD EL-HAY E.: Amelioration of iron-overload adverse effect by iron chelator in rats. J. Appl. Sci. Res., 5 (9): 1155-62, 2009.

65- VINA J., SASTRE J., PALLARDO F. and BORRAS C.: Mitochondrial theory of aging: Importance to explain why females live longer than males. Antioxid Redox Signal, 5 (5): 549-56, 2003.

66- KOEK G.H., LIEDORP P.R. and BAST A.: The role of oxidative stress in nonalcoholic steatohepatitis. Clin. Chim. Acta., 412 (15-16): 1297-305, 2011.

67- MADA S.B., REDDI S., KUMAR N., KUMAR R., KAPILA S., KAPILA R., et al.: Antioxidative peptide from milk exhibits antiosteopenic effects through inhibition of oxidative damage and bone-resorbing cytokines in ovariectomized rats. Nutrition, 43-44: 21-31, 2017.

68- YIN H., SHI Z.G., YU Y.S., HU J., WANG R., LUAN Z.P., et al.: Protection against osteoporosis by statins is linked to a reduction of oxidative stress and restoration of nitric oxide formation in aged and ovariectomized rats. Eur. J. Pharmacol., 674 (2-3): 200-6, 2012.

69- HOU Y.J., ZHAO Y.Y., XIONG B., CUI X.S., KIM N.H., XU Y.X., et al.: Mycotoxin-containing diet causes oxidative stress in the mouse. PLoS One, 8: e60374, 2013. 
70- VALKO M., MORRIS H. and CRONIN M.T.: Metals, toxicity and oxidative stress. Curr. Med. Chem., 12: 1161208, 2005.

71- ALTAMURA S. and MUCKENTHALER M.U.: Iron toxicity in diseases of aging: Alzheimer's disease, Parkinson's disease and atherosclerosis. J. Alzheimer's Dis., 16: 879-95, 2009

72- HERMOSO D.A., SHIMADA L.B., GILGLIONI E.H., CONSTANTIN J., MITO M.S., HERMOSO A.P., et al.: Melatonin protects female rats against steatosis and liver oxidative stress induced by oestrogen deficiency. Life Sci., 157: 178-86, 2016.

73- KANG J.W., HONG J.M. and LEE S.M.: Melatonin enhances mitophagy and mitochondrial biogenesis in rats with carbon tetrachloride-induced liver fibrosis. J. Pineal. Res., 60 (4): 383-93, 2016.

74- GOC Z., SZAROMA W., KAPUSTA E. and DZIUBEK K.: Protective effects of melatonin on the activity of SOD, CAT, GSH-Px and GSH content in organs of mice after administration of SNP. Chin. J. Physiol., 60 (1): 1-10, 2017.

75- EL-NEKEETY A.A., ABD EL-AZEIM S.H., HASSAN A.M., HASSAN N.S., ALY S.E. and ABD EL-WAHHAB M.A.: "Quercetin inhibits the cytotoxicity and oxidative stress in liver of rats fed aflatoxincontaminated diet", Toxicology Reports, 1: 319-29, 2014.

76- BISCHOFF S.C.: Quercetin: Potentials in the prevention and therapy of disease. Curr. Opin. Clin. Nutr. Metab. Care, 11 (6): 733-40, 2008.

77- VLACHODIMITROPOULOU E., NAFTALIN R.J. and SHARP PA.: Quercetin is a substrate for the transmembrane oxidoreductase Dcytb. Free Radic. Biol. Med., 48 (10): 1366-9, 2010.

78- LI Y., DENG Y., TANG Y., YU H., GAO C., LIU L., et al.: Quercetin protects rat hepatocytes from oxidative damage induced by ethanol and iron by maintaining intercellular liable iron pool. Hum. Exp. Toxicol., 33 (5): 534-41, 2014

79- KANKOFER M., RADZKI R.P., BIENKO M. and ALBERA E.: Antioxidative/oxidative status of rat liver after ovariectomy. J. Vet. Med. A. Physiol. Pathol. Clin. Med., 54: 225-9, 2007.

80- KOUHESTANI S., ZARE S. and BABAEI P.: Flavonoids Fraction of Mespilus Germanica Alleviates Insulin Resistance in Metabolic Syndrome Model of Ovariectomized Rats via Reduction in Tumor Necrosis Factor- a. J. Menopausal Med., 24 (3): 169-75, 2018.

81- LIVINGSTONE C. and COLLISON M.: "Sex steroids and insulin resistance," Clinical Science, 102 (2): 15166, 2002.

82- DONGIOVANNI P., RUSCICA M., RAMETTA R., RECALCATI S., STEFFANI L., GATTI S., et al.: Dietary iron overload induces visceral adipose tissue insulin resistance. Amer. J. Path., 182: 2254-63, 2013.

83- CHOI J.S., KOH I.U., LEE H.J., KIM W.H. and SONG J.: Effects of excess dietary iron and fat on glucose and lipid metabolism. J. Nutr. Biochem., 24: 1634-44, 2013.

84- GABRIELSEN J.S., GAO Y., SIMCOX J.A., HUANG J., THORUP D., JONES D.D., et al.: Adipocyte iron regulates adiponectin and insulin sensitivity. J. Clin. Invest., 122 (10): 3529-50, 2012.

85- GREEN A., BASILE R. and RUMBERGER J.M.: Transferrin and iron induce insulin resistance of glucose transport in adipocytes. Meta., 55: 1042-5, 2006.

86- SALONEN J.T., TUOMAINEN T.P., NYYSSÖNEN K., LAKKA H.M. and PUNNONEN K.: Relation between iron stores and non-insulin dependent diabetes in men: Case-control study. B.M.J., 317: 727, 1998.

87- FENG Y., QI R., XU M., SHEN Z. and LI M.: Dietary iron supplements may affect stress adaptation and aggravate stress hyperglycemia in a rat model of psychological stress Nutrition, 28: 691-7, 2012.

88- FARGION S., MATTIOLI M., FRACANZANI A.L., SAMPIETRO M., TAVAZZ D., FOCIANI P., et al.: Hyperferritinemia, iron overload, and multiple metabolic alterations identify patients at risk for nonalcoholic steatohepatitis. Amer. J. Gastro., 96: 2448-55, 2005.

89- RAJPATHAK S.N., CRANDALL J.P., WYLIE-ROSETT J., KABAT G.C., ROHAN T.E. and HU F.B.: The role of iron in type 2 diabetes in humans. Biochim. Biophys. Acta., 1790: 671-81, 2009.

90- BACKE M.B., MOEN I.W., ELLERVIK C., HANSEN J.B. and MANDRUP-POULSEN T.: Iron Regulation of pancreatic beta-cell functions and oxidative stress. Ann. Rev. Nutr., 36: 241-73, 2016.

91- SINGH P.K., BAXI D.B., MUKHERJEE R., POTNIS K.H. and RAMACHANDRAN A.V.: Supplementation with a polyherbal extract and melatonin together with exercise effectively reverses diabetic glycaemic status and carbohydrate metabolism and insulin level. Int. J. Biol. Med. Res., 1: 54-60, 2010.

92- STUMPF I., MUHLBAUER E. and PESCHKE E.: Involvement of the cGMP pathway in mediating the insulininhibitory effect of melatonin in pancreatic beta-cells. J. Pineal. Res., 45: 318-27, 2008.

93- RIVERA L., MORÓN R., SÁNCHEZ M., ZARZUELO A. and GALISTEO M.: Quercetin ameliorates metabolic syndrome and improves the inflammatory status in obese Zucker rats. Obesity (Silver Spring), 16 (9): 2081-7, 2008.

94- KOBORI M., MASUMOTO S., AKIMOTO Y. and TAKAHASHI Y.: Dietary quercetin alleviates diabetic symptoms and reduces streptozotocin-induced disturbance of hepatic gene expression in mice. Mol. Nutr. Food Res., 53 (7): 859-68, 2009.

95- COOKSEY R.C., JONES D., GABRIELSEN S., HUANG J., SIMCOX J.A., LUO B., et al.: Dietary iron restriction or iron chelation protects from diabetes and loss of betacell function in the obese (ob/ob Lep-/-) mouse. Am. J. Physiol. Endocrinol. Metab., 298 (6): 1236-43, 2010.

96- MEHDAD A., CAMPOS N.A., ARRUDA S.F. and SIQUEIRA E.M.: Iron Deprivation May Enhance Insulin Receptor and Glut4 Transcription in Skeletal Muscle of Adult Rats. J. Nutr. Health Aging., 19 (8): 846-54, 2015.

97- EVANS J.L., MADDUX B.A. and GOLDFINE I.D.: The molecular basis for oxidative stress-induced insulin resistance. Antioxid. Redox Signal., 7 (7-8): 1040-52, 2005.

98- MADDUX B.A., SEE W., LAWRENCE J.C.J.R., GOLDFINE A.L., GOLDFINE I.D. and EVANS J.L.: Protection against oxidative stress-induced insulin resistance in rat 
L6 muscle cells by micromolar concentrations of a-lipoic acid. Diabetes, 50: 404-10, 2001.

99- JACOB S., RUUS P., HERMANN R., TRITSCHLER H.J., MAERKER E., RENN W., et al.: Oral administration of RAC-a-lipoic acid modulates insulin sensitivity in patients with type 2 diabetes mellitus: A placebo-controlled pilot trial. Free Radic. Biol. Med., 27: 309-14, 1999.

1 00- ISHIKAWA A., YAMASHITA H., HIEMORI M., INAGAKI E., KIMOTO M., OKAMOTO M., et al.: Characterization of inhibitors of postprandial hyperglycemia fromthe leaves of Nerium indicum. J. Nutr. Sci. Vitaminol., 53: 166-73, 2007.

101- JO S.H., KA E.H. LEE H.S., APOSTOLIDIS E., JANG H.D. and KWON Y.I.: Comparison of antioxidant potential and rat intestinal $\alpha$-glucosidases inhibitory activities of quercetin, rutin, and isoquercetin. Int. J. Appl. Res. Nat. Prod., 2: 52-60, 2009.

102- ALAM M.M., MEERZA D. and NASEEM I.: Protective effect of quercetin on hyperglycemia, oxidative stress and DNA damage in alloxan induced type 2 diabetic mice. Life Sci., 109 (1): 8-14, 2014.

1 03- PENG J., LI Q., LI K., ZHU L., LIN X., LIN X., et al.: Quercetin Improves Glucose and Lipid Metabolism of Diabetic Rats: Involvement of Akt Signaling and SIRT1. J. Diabetes Res., 2017: ID 3417306, 2017.

104- JEONG Y.H., HUR H.J., JEON E.J., PARK S.J., HWANG J.T., LEE A.S., et al.: Honokiol Improves Liver Steatosis in Ovariectomized Mice. Molecules., 23 (1): E194, 2018.

105- SIGNORELLI S.S., NERI S., SCIACCHITANO S., PINO L.D., COSTA M.P., MARCHESE G., et al.: Behaviour of some indicators of oxidative stress in postmenopausal and fertile women. Maturitas, 53: 77-82, 2006.

106- MCMANUS J., MCENENY J., YOUNG I.S. and THOMPSON W.: The effect of various oestrogens and progestogens on the susceptibility of low-density lipoproteins to oxidation in vitro. Maturitas, 25 (2): 125-3 1, 1996.

107- WALSH B.W., SCHIFF I. and ROSNER B.: Effects of postmenopausal estrogen replacement on the concentration and metabolism of lipoproteins. N. Engl. J. Med., 325: 196-204, 1991.

108- BERG G., HALPERIN H., SISELES N. and WIKINSKI R.: Very low-density lipoproteins and subclasses of intermediate density lipoproteins in postmenopausal women. Medicina, 56: 479-86, 1996.

109- MOORADIAN A.D.: "Dyslipidemia in type 2 diabetes mellitus," Nature Clinical Practice Endocrinology and Metabolism, 5 (3): 150-9, 2009.

1 10- SYLVAIN B., LOUISE T., EDGARD D., WAGNER Y., MOÏSE B. and EMILE L.: Dietary iron overload and induced lipid peroxidation are associated with impaired plasma lipid transport and hepatic sterol metabolism in rats. Hepatology, 29: 1809-17, 2003.

111- WHITTAKER P. and CHANDERBHAN RF.: Effect of increasing iron supplementation on blood lipids in rats. Br. J. Nutr., 86: 587-92, 2001.

112- BRUNT E.M.: Nonalcoholic steatohepatitis: Definition and pathology. Semin. Liver Dis., 21: 3-16, 2001.
113- FORETZ M., FOUFELLE F. and FERRÉ P.: Polyunsaturated fatty acids inhibit fatty acid synthase and spot14-protein gene expression in cultured rat hepatocytes by a peroxidative mechanism. Biochem. J., 341: 371-6, 1999.

114- BRUNET S., THIBAULT L., DELVIN E., YOTOV W., BENDAYAN M. and LEVY E.: Dietary iron overload and induced lipid peroxidation are associated with impaired plasma lipid transport and hepatic sterol metabolism in rats. Hepatology, 29: 1809-17, 1999.

115- KOZIROG M., POLIWCZAK A.R., DUCHNOWICZ P., KOTER-MICHALAK M., SIKORA J. and BRONCEL M.: Melatonin treatment improves blood pressure, lipid profile, and parameters of oxidative stress in patients with metabolic syndrome. J. Pineal. Res., 50: 261-6, 2011.

116- TAMURA H., NAKAMURA Y., NARIMATSU A., YAMAGATA Y., TAKASAKI A., REITER R.J., et al.: Melatonin treatment in peri-and postmenopausal women elevates serum high-density lipoprotein cholesterol levels without influencing total cholesterol levels. J. Pineal Res., 45: 101-5, 2008.

117- JEONG S.M., KANG M.J., CHOI H.N., KIM J.H. and KIM J.I.: Quercetin ameliorates hyperglycemia and dyslipidemia and improves antioxidant status in type 2 diabetic db/db mice. Nutr. Res. Pract., 6 (3): 201-7, 2012.

118- JIANG R., MANSON J.E., MEIGS J.B., MA J., RIFAI N. and HU F.B.: Body iron stores in relation to risk of type 2 diabetes in apparently healthy women. J.A.M.A., 291 (6): 711-7, 2004.

119- MINAMIYAMA Y., TAKEMURA S., KODAI S., SHINKAWA H., TSUKIOKA T., ICHIKAWA H., et al.: Iron restriction improves type 2 diabetes mellitus in Otsuka Long-Evans Tokushima fatty rats. Am. J. Physiol. Endocrinol. Metabol., 298 (6): 1140-9, 2010.

120- BOREL M.J., BEARD J.L. and FARRELL P.A.: Hepatic glucose production and insulin sensitivity and responsiveness in iron-deficient anemic rats. Am. J. Physiol., 264 (3): 380-90, 1993.

121- MOZAFFARI S., HASANI-RANJBAR S. and ABDOLLAHI M.: The Mechanisms of Positive Effects of Melatonin in Dyslipidemia: A Systematic Review of Animal and Human Studies. International Journal of Pharmacology, 8: 496-509, 2012.

122- BRONCEL M., KOZIROG-KOLACINSKA M. and CHOJNOWSKA-JEZIERSKA J.: Melatonin in the treatment of atherosclerosis. Pol. Merkur. Lekarski., 23: 1247, 2007.

123- KOPPISETTI S., JENIGIRI B., TERRON M.P., TENGATTINI S., TAMURA H., FLORES L.J., et al.: Reactive oxygen species and the hypomotility of the gall bladder as targets for the treatment of gallstones with melatonin: A review. Dig. Dis. Sci., 53: 2592-603, 2008.

124- KRYCER J.R., SHARPE L.J., LUU W. and BROWN A.J.: "The Akt-SREBP nexus: cell signaling meets lipid metabolism," Trends in Endocrinology \& Metabolism, 21 (5): 268-76, 2010.

125- HAO J., CHEN C., HUANG K. HUANG J., LI J., LIU P., et al.: "Polydatin improves glucose and lipid metabolism in experimental diabetes through activating the 
Akt signaling pathway," European Journal of Pharmacology, 745: 152-65, 2014.

126- GNONI G.V., PAGLIALONGA G. and SICULELLA L.: Quercetin inhibits fatty acid and triacylglycerol synthesis in rat-liver cells. Eur. J. Clin. Invest., 39: 761-8, 2009.

127- HUSSAN F., IBRAHEEM N.G., KAMARUDIN T.A., SHUID A.N., SOELAIMAN I.N. and OTHMAN F.: Curcumin Protects against Ovariectomy-Induced Bone Changes in Rat Model. Evidence-Based Complementary and Alternative Medicine, 2012: ID 174916, 2012.

128- WU T., ZHANG Y., YUAN H., WU G., LI B. and CUIPREVENTIVE L.: Effects of Salvianolic acid B on osteopenia of rats induced by ovariectomy. Bone, 43 (1): 75-6, 2008.

129- SARMA U., EDWARDS M., MOTOYOSHI K. and FLANAGAN A.M.: "Inhibition of bone resorption by 17 beta-estradiol in human bone marrow cultures," Journal of Cellular Physiology, 175: 99-108, 1998.

130- PARHAMI F.: "Possible role of oxidized lipids in osteoporosis: Could hyperlipidemia be a risk factor?" Prostaglandins Leukotrienes and Essential Fatty Acids, 68 (6): 373-8, 2003.

131- LIU B.Y., WU P.W., BRINGHURST F.R. and WANG J.T.: Estrogen inhibition of PTH stimulated osteoclast formation and attachment. In vitro: Involvement of both PKA and PKC. Endocrinology, 143 (2): 627-35, 2002.

132- KALINOWSKI D.S. and RICHARDSON D.R.: The evolution of iron chelators for the treatment of iron overload disease and cancer. Pharmacol. Rev., 57: 547 83,2005

133- ISHII K.A., FUMOTO T., IWAI K., TAKESHITA S., ITO M., SHIMOHATA N., et al.: Coordination of PGC1 beta and iron uptake in mitochondrial biogenesis and osteoclast activation. Nat. Med., 15: 259-66, 2009.

134-YAMASAKI K. and HAGIWARA H.: Excess iron inhibits osteoblastmetabolism. Toxicol. Lett., 191: 211-15, 2009.

135- TSAY J., YANG Z., ROSS F.P., CUNNINGHAMRUNDLES S., LIN H., COLEMAN R., et al.: Bone loss caused by iron overload in a murine model: Importance of oxidative stress. Blood, 116: 2582-9, 2010.

136- WANG Q.L., HUO X.C., WANG J.H., WANG D.P., ZHU Q.L., LIU B., et al.: Rutin prevents the ovariectomyinduced osteoporosis in rats. Eur. Rev. Med. Pharmacol. Sci., 21 (8): 1911-7, 2017.

137- ZARJOU A., JENEY V., AROSIO P., POLI M., ZAVACZKI E., BALLA G., et al.: Ferritin ferroxidase activity: A potent inhibitor of osteogenesis. J. Bone Miner. Res., 25: $164-72,2010$
138- LADIZESKY M.G., CUTRERA R.A., BOGGIO V., SOMOZA J., CENTRELLA J.M., MAUTALEN C., et al.: Effect of melatonin on bone metabolism in ovariectomized rats. Life Sci., 70 (5): 557-65, 2001.

139- TSUJI M., YAMAMOTO H., SATO T., MIZUHA Y., KAWAI Y., TAKETANI Y., et al.: Dietary quercetin inhibits bone loss without effect on the uterus in ovariectomized mice. J. Bone. Miner. Metab., 27: 673-81, 2009.

140- LIANG W., LUO Z., GE S., LI M., DU J., YANG M., et al.: Oral administration of quercetin inhibits bone loss in rat model of diabetic osteopenia. Eur. J. Pharmacol., 670 (1): 317-24, 2011.

141- LIU G., MEN P., KENNER G.H. and MILLER S.C.: Therapeutic effects of an oral chelator targeting skeletal tissue damage in experimental postmenopausal osteoporosis in rats. Hemoglobin, 32: 181-90, 2008

142- ORSOLIC' N., JELEC Z., NEMRAVA J., BALTA V., GREGOROVIC' $\mathrm{G}$. and JELEC D.: Effect of Quercetin on Bone Mineral Status and Markers of Bone Turnover in Retinoic Acid-Induced Osteoporosis, Polish Journal of Food and Nutrition Sciences, 68 (2): 149-62, 2018.

143- NAKADE O., KOYAMA H., ARIJI H., YAJIMA A. and KAKU T.: Melatonin stimulates proliferation and type I collagen synthesis in human bone cells in vitro. J. Pineal. Res., 27: 106-10, 1999.

144- ROTH J.A., KIM B.G., LIN W.L. and CHO M.I.: Melatonin promotes osteoblast differentiation and bone formation. J. Biol. Chem., 274: 22041-7, 1999.

145- PROUILLET C., MAZIÈRE J.C., MAZIÈRE C., WATTEL A., BRAZIER M. and KAMEL S.: Stimulatory effect of naturally occurring flavonols quercetin and kaempferol on alkaline phosphatase activity in MG-63 human osteoblasts through ERK and estrogen receptor pathway. Biochem. Pharmacol., 67: 1307-13, 2004.

146- WATTEL A., KAMEL S., PROUILLET C., PETIT J.P LORGET F., OFFORD E., et al.: Flavonoid quercetin decreases osteoclastic differentiation induced by RANKL via a mechanism involving NF kappa B and AP-1. J. Cell. Biochem., 92: 285-95, 2004.

147-WOO J.T., NAKAGAWA H., NOTOYA M., YONEZAWA T., UDAGAWA N., LEE I.S., et al.: Quercetin suppresses bone resorption by inhibiting the differentiation and activation of osteoclasts. Biol. Pharm. Bull., 27: 504-9, 2004.

148- INOUE J., CHOI J.M., YOSHIDOMI T., YASHIRO T, and SATO R.: Quercetin enhances VDR activity, leading to stimulation of its target gene expression in Caco-2 cells. Nutr. Sci. Vitaminol., 56: 326-30, 2010. 


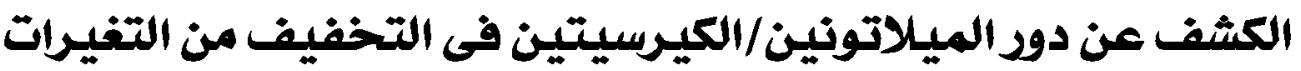

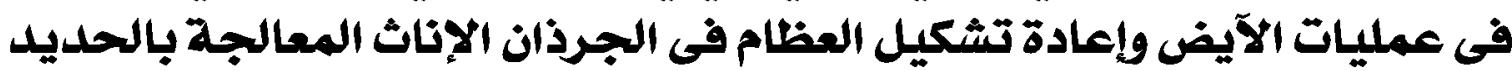 بعل إستئصال المبيضين فئمين}

الهدف: تهدف هذه الدراسة إلى تقييم الدود المحتمل لتراكم الحديد في تدهور التغيرات في عمليات الآيض وإعادة تشكيل العظام الناجمة

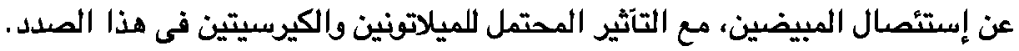

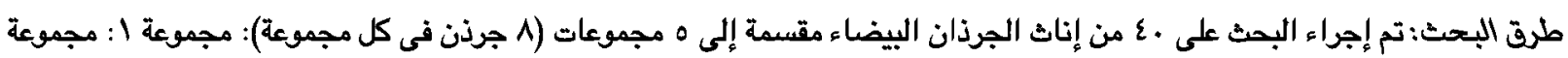

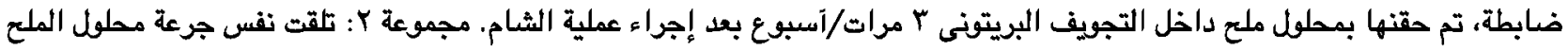

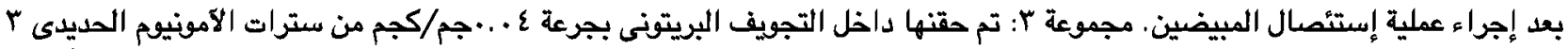

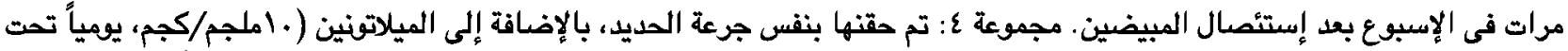

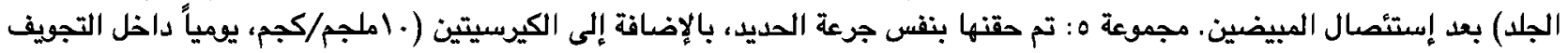
البريتونى) بعد إستئصال المبيضين.

فوفى نهاية التجارب تم ذبح الجرذان وتجميع عينات الدم لقياس الحديد، الفريتين، عوامل الإجهاد التاكسدى، نسبة الجلوكوذ والآنسولين

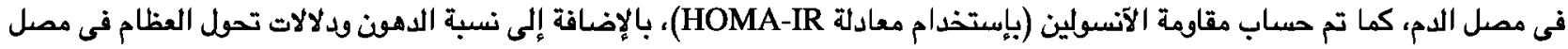

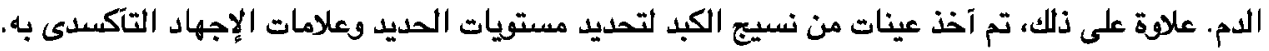

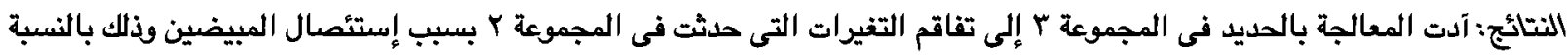

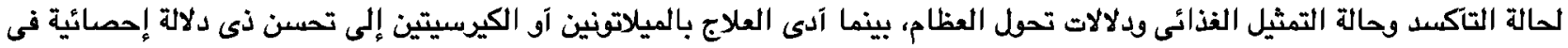

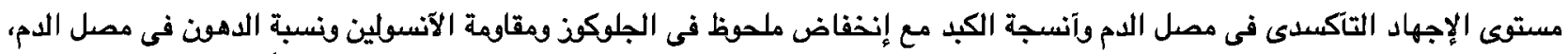

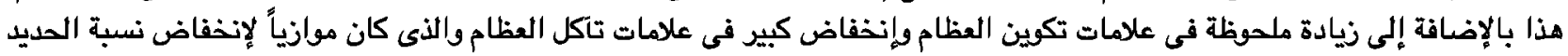

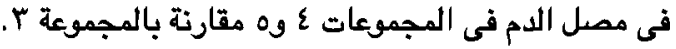

الخلاصة: هذه النتائج تشير إلى الآثار المفيدة اللعلاج بالميلاتونين آو الكيرسيتين فى تصسين التغيرات في عمليات الآيض وإعادة تثكيل العظام الناجمة عن تراكم الحديد في الجرذان المعالجة المبان بالحديد بعد إستئصال المبيضين. 